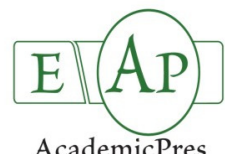

AcademicPres

\title{
Alien Species of Lepidium in the Flora of Romania: Invasion History and Habitat Preference
}

\author{
Culiță SÎRBU ${ }^{1 *}$, Adrian OPREA², Cristian Valeriu PATRICHE \\ Costel SAMUIL ${ }^{1}$, Vasile VÎNTU ${ }^{1}$ \\ ${ }^{1}$ University of Agricultural Sciences and Veterinary Medicine Iaşi, Faculty of Agriculture, 3, Mihail Sadoveanu Alley, 700490, Iaşi, Romania; \\ csirbu@uaiasi.ro(*correspondingauthor);vvintu@uaiasi.ro; csamuil@uaiasi.ro \\ ${ }^{2}$ University "Alexandru Ioan Cuza”, Botanical Garden, 7-9, Dumbrava Roşie Street, 700487, Iaşi, Romania; aoprea@uaic.ro \\ ${ }^{3}$ Romanian Academy, Department of Iaşi, Geography Group, B-dul Carol I, 8, 700505, Iaşi, Romania; pvcristi@yahoo.com
}

\begin{abstract}
The history of spread and habitat preferences during invasion of four alien species of Lepidium in Romania, namely $L$. densiflorum, L. oblongum, L. sativum, and L. virginicum are presented in this paper. The floristic records of these species, collected between 1816 and 2013, were used in the study. L. sativum was sporadically mentioned by earlier botanic references, as a casual alien plant in ruderal places. L. oblongum was reported from a single locality, but it may be considered a potential invader of ruderal habitats from southern regions. For $L$. densiflorum and L. virginicum, distribution maps were made in the Universal Transverse Mercator system, and exponential regression models were fitted to the cumulative number of records against time. Both $L$. densiflorum and L. virginicum are invasive in Romania, and their spread was initiated at the middle of last century. The slope of invasion curves, which was used as a measure of the invasion rate, did not differ significantly between the two invasive species. Although both L. densiflorum and L. virginicum were first reported in the North-West of the country, they followed different paths of migration in Romania. Ruderal habitats associated with railways played an important role in the invasion process of both species, but invaded habitats became more diversified over the time. Among the four species, only L. densiflorum tends to invade agricultural crops.
\end{abstract}

Keywords: distribution map, herbarium specimen, non-native weeds, transportation routes

\section{Introduction}

The genus Lepidium $\mathrm{L}$. is one of the largest genera in the Brassicaceae family, being distributed on all continents, except Antarctica (Al-Shehbaz and Gaskin, 2010). In the alien flora of Europe, the genus Lepidium is currently represented by 20 species, of which 11 are from outside of Europe, and nine are native in certain regions of the continent, but alien outside of their native range (Drake, 2009). Among these, three species were recorded in Romania (Ciocârlan, 2009), namely: L. virginicum L., $L$. densiflorum Schrader (including L. neglectum Thell.), and $L$. sativum L. All these three species are listed among the most widespread alien plant species in Europe (Lambdon et al., 2008). A fourth alien species, L. oblongum Small, was newly reported from Romania by Sîrbu and Oprea (2011).

In order to understand causes of invasions, and develop successful management strategies for invasive alien species, a useful tool is the reconstructing of the spread history of invasive plants, using data from herbaria (Chauvel et al., 2006; Crawford and Hoagland, 2009; Csontos et al., 2010;
Delisle et al., 2003; Lavoie et al., 2007), monographs (Mihulka and Pyšek, 2001), or from multiple floristic sources in a given region (i.e. herbaria, literature and unpublished records) (Essl et al., 2009; Pyšek and Prach, 1993; Williamson et al., 2005). Maps based on historical floristic records can indicate points of introduction, invasion pathways, rates of spread and other data on the spreading of alien plants in the invaded areas (Csontos et al., 2010; Lavoie et al., 2007).

In this study, we aimed to reconstruct the history of spread and habitat preferences of alien species of Lepidium in Romania, using all the available data from herbaria and literature, as well as our own recent unpublished records.

\section{Materials and methods}

In order to reconstruct the history of invasion and habitat preferences of alien species of Lepidium in Romania, all occurrence data up to 2013 were registered. The information was gathered from literature (see Sîrbu and Oprea (2011) for primary sources of data), public herbaria, and recent records of the authors (2012-2013). 
Herbarium data were collected from the following main herbaria of Romania (abbreviations according to Holmgren et al., 1990): BUAG, BUC, BUCA, BUCM, CL, CLA, CRAI, I, IAGB, and IASI. In addition, some smaller collections were investigated, from Bacău, Oradea, and Tg. Mureş cities.

Each herbarium specimen was checked out for correct identification, sampling location, date of sampling, and habitat characteristics. The date of collection on the specimen label (for herbarium data), or the publication year (for the data from literature) unless other specific information from the fieldwork was given, were accepted as data of presence of a certain species in a given area. Repeated reports on the occurrence of a species from the same locality and the same year were treated as a single record. The nomenclature of Lepidium taxa follows Al-Shehbaz and Gaskin (2010).

The status of populations (naturalized or nonnaturalized) was assessed for each record according to the terminology and definitions recommended by Richardson et al. (2000), and the pattern used by Essl et al. (2009). Populations were considered naturalized, if (i) this status has resulted unambiguously in the original data source, (ii) populations consisted of a large number of reproductive individuals (more than 100), (iii) populations smaller than 100 individuals were reported in the same location at least two consecutive years, or several small populations were recorded in the same locality, the same year. In all other cases, populations were considered non-naturalized.

The distribution maps of $L$. densiflorum and $L$. virginicum in Romania were made using the Universal Transverse Mercator (UTM) grid system (Lehrer and Lehrer, 1990). All records of these two species were marked on the map based on the locality code from UTM grid with cells of $10 \times 10 \mathrm{~km}$.

In order to obtain a global estimation of the invasion rate for $L$. densiflorum and $L$. virginicum, exponential regression models $\left(y=e^{a+b x}\right)$ were fitted to the cumulative number of records against time and the slope $b$ was used as a measure of the invasion rate (Delisle et al., 2003; Mihulka and Pyšek, 2001; Pyšek and Prach, 1993). The significance of difference between the slopes was tested using the $t$-test of parallelism (Zar, 2010). We also tested, for these two species, whether the length of the railway network $(\mathrm{km})$, as well as the rail traffic intensity of freight (tons per year) and people (thousand passengers per year), between 1950 and 2010, was positively related to the number of records by calculating the Spearman's correlation coefficients $\left(r_{s}\right)$, with right-tail tests of significance (Zar, 2010). To assess habitat preferences of $L$. densiflorum and L. virginicum, a $\mathrm{G}^{2}$-test of independence (McDonald, 2008) was performed on the observed frequencies of species in various habitat types. The program XLSTAT (version 2011) was used for statistical analyses.

\section{Results}

\section{General result}

A total number of 174 records of four alien species of Lepidium (L. sativum L., L. densiflorum Schrad., $L$. virginicum $\mathrm{L}$., and $L$. oblongum Small) have been reported in
Romania in a period of 197 years (between 1816 and 2013). Of these, 62 records were obtained from 92 herbarium sheets, 94 from literature sources, and 18 from field investigations (2012-2013). Herbarium data were recorded in 13 public herbaria, of which the most important was IASI (38 specimens). Four herbaria contained no specimens of alien species of Lepidium.

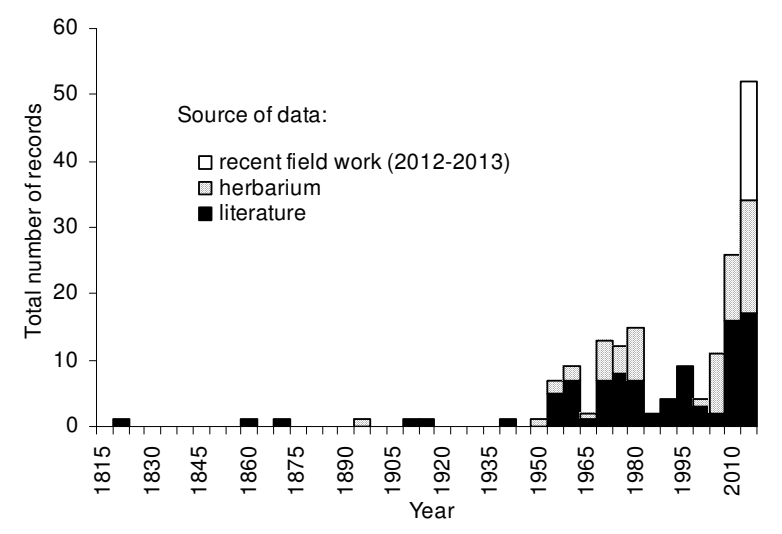

Fig. 1. Distribution of the total number of records of the alien species of Lepidium in Romania, between 1816 and 2013

Four periods of intensive recording of alien species of Lepidium can be distinguished (Fig. 1), of which the most important was between 2004 and 2013. Herbarium specimens were collected especially between 1966 and 1980 and between 2004 and 2013.

\section{History of invasion and distribution}

Lepidium sativum was the first alien species of Lepidium reported in Romania, in 1816. Until 1955, this species was reported only in 6 localities, and there are no reliable data on its naturalization in Romania. Since 1955 the species was no longer reported. All specimens of $L$. sativum from various herbaria were collected from vegetable gardens.

Historical data on the distribution of $L$. densiflorum and L. virginicum in Romania are represented on the maps in Fig. 2 and Fig. 3, respectively.

Lepidium densiflorum was first observed in Romania in the province of Crişana (1893), and later on in Transylvania (1958), Moldavia (1967), Muntenia (1968), Oltenia (1976), and Dobrudja (2011). Overall, L. densiflorum has been reported so far from 110 UTM cells of $100 \mathrm{~km}^{2}$ (i.e., $4.6 \%$ of the country area), corresponding to 89 localities, of which $1.1 \%$ before $1950,41.6 \%$ between 1951 and 2000, and $57.3 \%$ after the year 2000. This species is widespread in the eastern half of Romania, mainly in Moldavia (60 localities) and Muntenia (11 localities), and it is less widespread in the western half of the country. In Maramureş and Banat it has not been reported so far. The first reliable data on naturalized populations of this species in Romania dates back to 1967, in Moldavia. Until 2013, $L$. densiflorum has been reported in Romania, as a 
241

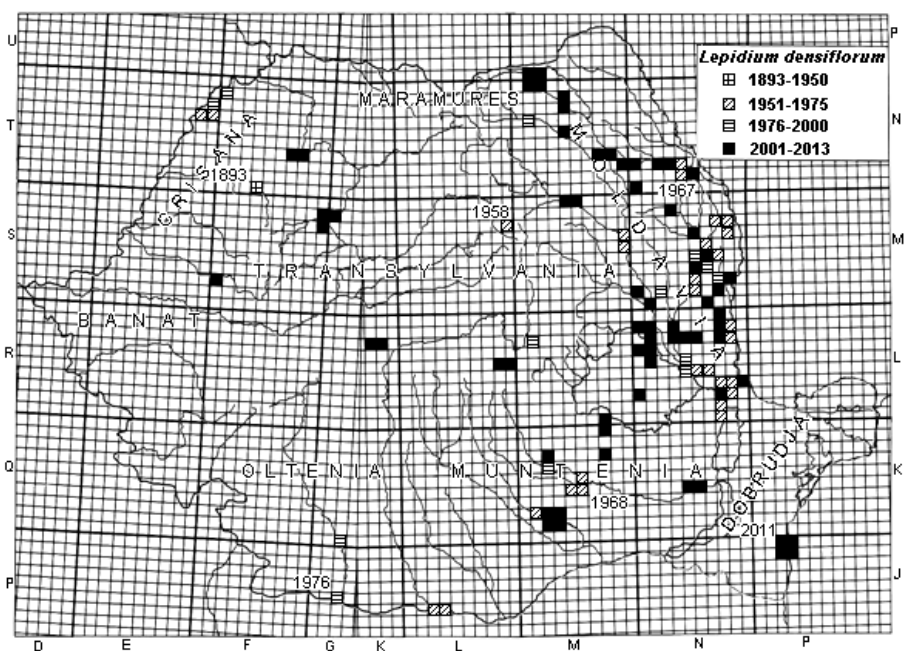

Fig. 2. Distribution of Lepidium densiflorum in Romania, between 1893 and 2013, by species occurrence within UTM cells of 10 $\mathrm{x} 10 \mathrm{~km}$. The years of the oldest records for each historical region were indicated

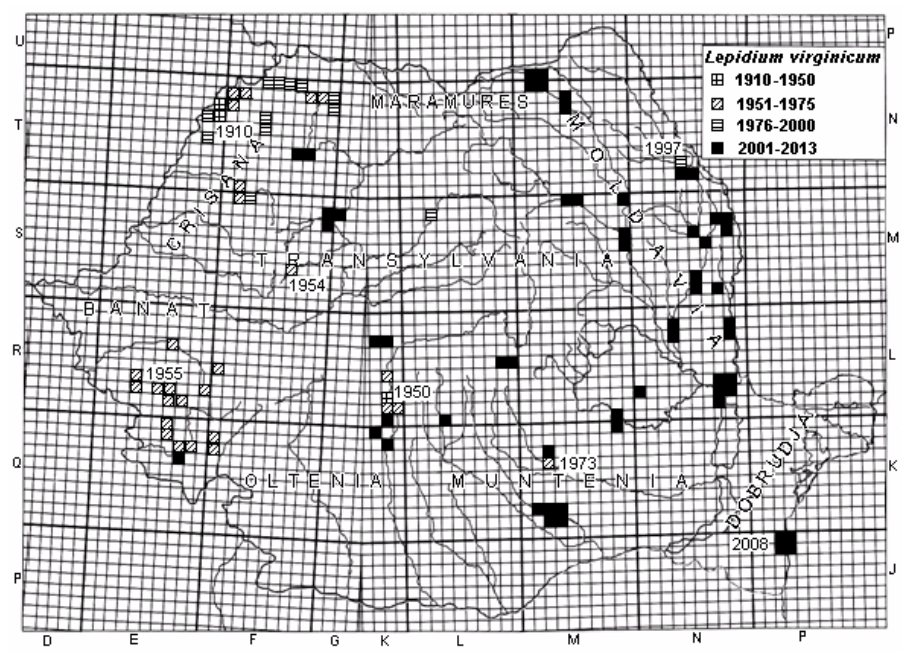

Fig. 3. Distribution of Lepidium virginicum in Romania, between 1910 and 2013, by species occurrence within UTM cells of $10 \mathrm{x}$ $10 \mathrm{~km}$. Meaning of numbers displayed as in Fig. 2

naturalized species, from 59 localities (which is $66.3 \%$ of all records), of which 51 localities (86.4\%) after the year 2000 .

Lepidium virginicum was first documented in 1910, in Crişana, and subsequently in Oltenia (1950), Banat (1955), Transylvania (1962), Muntenia (1973), Maramureş (1974), Moldavia (1997), and Dobrudja (2009). The occurrence of L. virginicum has been reported so far from 101 UTM cells of $100 \mathrm{~km}^{2}$ (i.e. $4.2 \%$ of the country area), corresponding to 76 localities, of which $2.6 \%$ between 1910 and $1950,48.7 \%$ between 1950 and 1999, and 48.7\% after the year 2000 . Nowadays, this species has spread to all historical provinces of Romania, being more frequent in Moldavia (22 localities), Crişana (16 localities), and Banat (12 localities). In Oltenia, Muntenia, and Transylvania it is sporadic, while in Dobrudja and Maramureş, it is rare. The first record of a naturalized population was in 1955, in Banat. Until 2013, this species has been reported as naturalized in 32 localities (which is $42.1 \%$ of all records), of which 27 localities (84.4\%) after the year 2000 .

The slopes of invasion curves of $L$. densiflorum and $L$. virginicum (Fig. 4) do not differ significantly from each

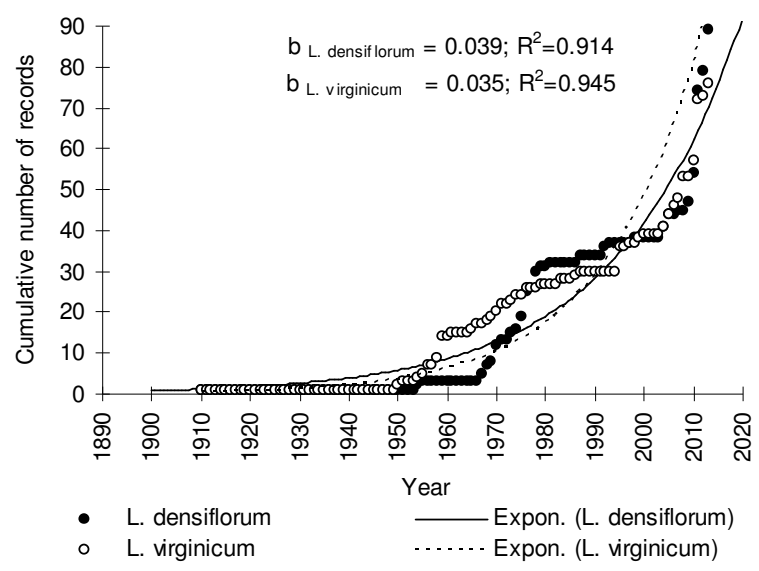

Fig. 4. Exponential regression curves of the cumulative number of records of Lepidium densiflorum and $L$. virginicum in Romania. The estimated invasion rates (slopes b) are both statistically different from zero at $5 \%$ probability level 
other (test of parallelism: $\mathrm{t}=0.207, \mathrm{P}=0.836$ ). Two periods of invasiveness (i.e. sharp increase of the lines of distribution) can be distinguished for both $L$. densiflorum (i.e. between 1967-1979, and 2004-2013, respectively) and L. virginicum (i.e. 1950-1976, and 1995-2013, respectively).

No significant positive relationships were found between the length of railway network $(\mathrm{km})$ and the number of records of $L$. densiflorum and L. virginicum $\left(\mathrm{r}_{\mathrm{s}}=\right.$ $-0.003, \mathrm{p}=0.491 ; \mathrm{r}_{\mathrm{s}}=-0.438, \mathrm{p}=0.001$, respectively). In addition, no significant positive relationships were found between the rail traffic of goods (thousand tonnes per year) or passengers (thousand passengers per year) for the period 1950-2010 and number of records of species L. densiflorum $\left(\mathrm{r}_{\mathrm{s}}=0.118, \mathrm{p}=0.183 ; \mathrm{r}_{\mathrm{s}}=-0.068, \mathrm{p}=0.301\right.$, respectively $)$ and $L$. virginicum $\left(\mathrm{r}_{\mathrm{s}}=-0.387, \mathrm{p}=0.001 ; \mathrm{r}_{\mathrm{s}}=-0.382, \mathrm{p}=\right.$ 0.001 , respectively).

The most recent alien species of Lepidium recorded in Romania's flora is L. oblongum (Fig. 5). It was found in 2011 , only in a single locality, in the railway station of Râmnicu Sărat, Buzău County, between the platform of the station and the rail lines.

\section{Habitat preferences over time.}

Two of the species considered in this paper were observed each in a single type of habitat, namely, ruderal habitats near gardens (L. sativum) or associated with railways (L. oblongum). The proportion of each habitat types invaded over time by the other two species $(L$.

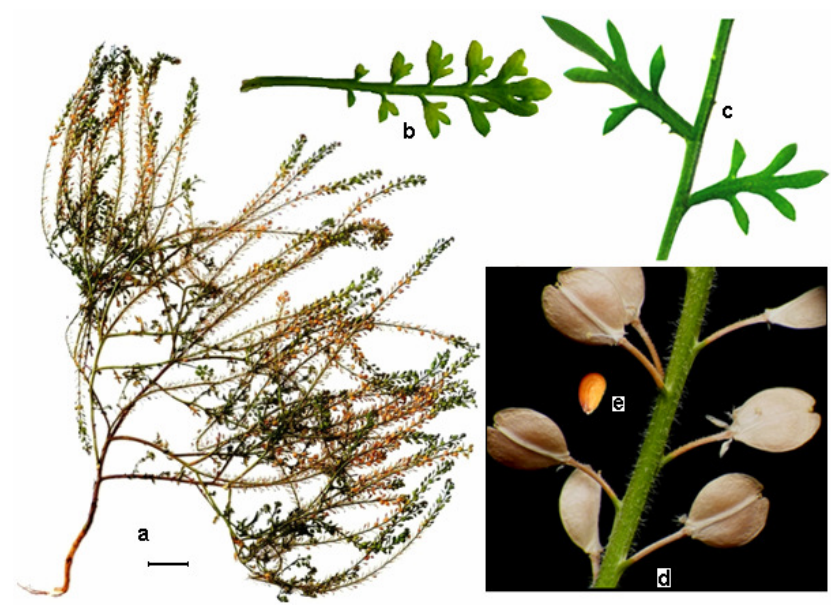

Fig. 5. Lepidium oblongum: a) herbarium specimen, b) basal leaf, c) upper cauline leaves; d) fruits, e) seed. Scale bar: $a=20$ $\mathrm{mm}, \mathrm{b}=10 \mathrm{~mm}, \mathrm{c}=5 \mathrm{~mm}, \mathrm{~d}, \mathrm{e}=1 \mathrm{~mm}$

densiflorum and L. virginicum) is shown in Fig. 6. The difference in invaded habitat types between $L$. densiflorum and L. virginicum was significant (Wilks' $\mathrm{G}^{2}=14.07$, d.f. $=7$; $\mathrm{p}=0.041$ ).

Since $1883 \mathrm{~L}$. densiflorum has been mainly recorded in ruderal places associated with railways. Diversification of habitats invaded by this species began in the late 1960s, when it was collected from floodplains of some rivers. Since 1970 s, it has been also observed in harbours, cereal crops or vineyards on sandy soils, along roadsides and in other ruderal habitats, as well as on sandy lands. However, in recent decades, a significant diversification of invaded habitats has not been further registered. The main habitats,

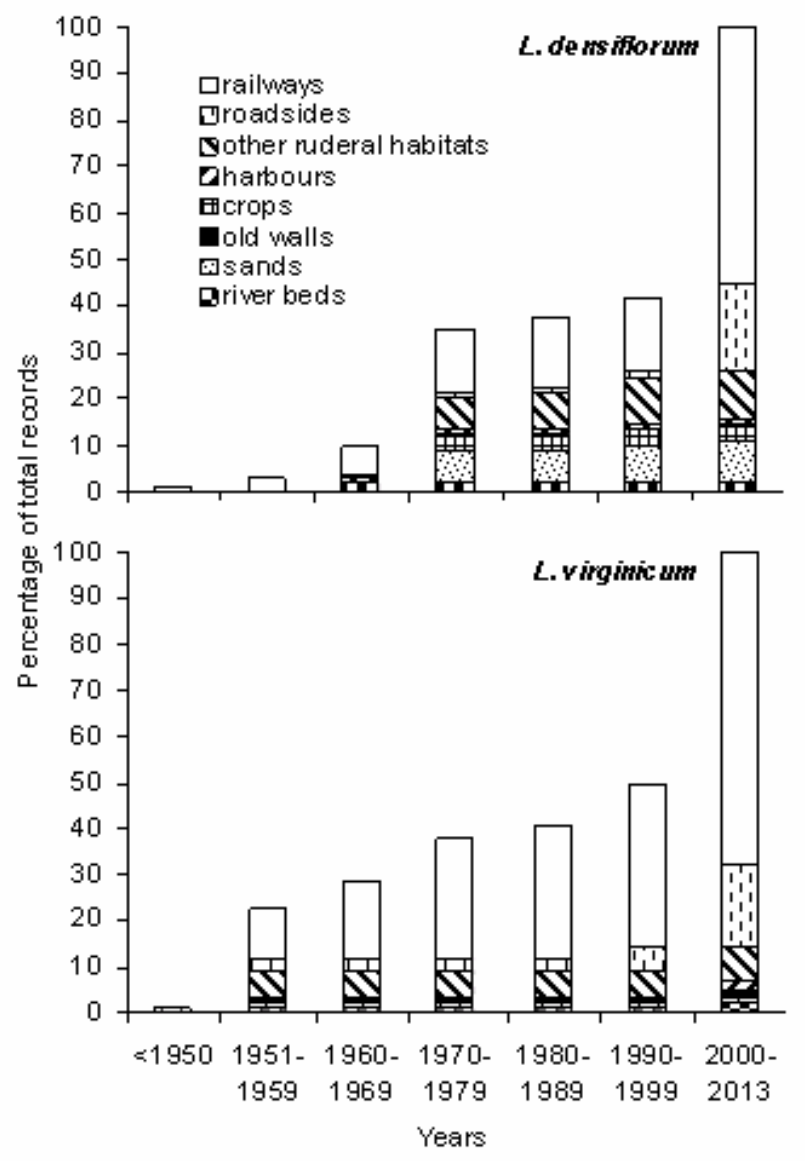

Fig. 6. Relative frequency of habitat types invaded over time in Romania by Lepidium densiflorum and L. virginicum

in which $L$. densiflorum has been observed since 1980 are represented by railways and, to a lesser extent, roadsides and other ruderal sites.

Lepidium virginicum has been mainly recorded along railways. To a lesser extent, this species invaded roadsides and other ruderal habitats. It was also observed on ruderalized sands, on old walls, on sandy gravels of river beds, as well as in harbours. It has not been recorded until now as a weed in crops.

\section{Discussion}

\section{General distribution and invasion history}

Lepidium sativum originated in North-East Africa and South-West Asia, being cultivated since ancient times as a vegetable or as a herb (Jansen, 2004; Markgraf, 1963; Thellung, 1906). According to Akeroyd and Rich (2010), it is frequent as a casual weed and locally naturalized in Europe, but it is impossible from the available data to distinguish between naturalized and casual distribution. However, Lambdon et al. (2008) listed this species among the most widespread 20 alien plant species in Europe. $L$. sativum was also reported as naturalized in North America, South America (Argentina), Australia (Al-Shehbaz, 2010), and Eastern Asia (Taiyan et al., 2001). 
243

We suppose $L$. sativum was introduced in Romania as a vegetable, before the nineteenth century, when it was first reported from Transylvania (Baumgarten, 1816). Up to the middle of the last century, this species was mentioned sporadically in the literature, as a subspontaneous plant, escaped from gardens (Nyárády, 1955), in Transylvania (Baumgarten, 1816; Schur, 1866), Banat (Heuffel, 1858), Muntenia (Panțu, 1912) and Bukovina (Prodan, 1939). However, according to Simonkai (1886), L. sativum was found in Transylvania only as a cultivated plant. After 1955, this species has not been reported from other localities in Romania, and nowadays it is rarely cultivated as a vegetable. All the examined specimens of $L$. sativum, from herbaria, were collected from gardens. Therefore $L$. sativum can be considered as a casual alien plant in Romania, based only on old data from the literature.

Lepidium densiflorum is a species native to North America, recorded as a casual alien after 1870 in Central Europe (Markgraf, 1963). Nowadays, it is naturalized in most of Europe, except in Great Britain, the Iberian Peninsula and the Balkan Peninsula (Akeroyd and Rich, 2010), being listed among the 100 most widespread alien plant species in the continent (Lambdon et al., 2008). It is also naturalized in South America (Al-Shehbaz, 2010) and Asia (Taiyan et al., 2001). In the neighbouring countries of Romania, $L$. densiflorum has been known since 1895 in Ukraine (Protopopova et al., 2006), and since 1935, in Hungary (Pénzes, 1941).

The presence of $L$. densiflorum in Romania was first reported by Negrean (1980), based on herbarium specimens collected by the author in several localities, as well as on the revision of some earlier herbarium collections that had been erroneously identified as $L$. virginicum. The first record of this species in Romania is a specimen collected by Richter, in 1893, in the northwestern part of the country (Crişana), at Ciucea village. According to Negrean (1980), this specimen was first assigned to $L$. virginicum, and subsequently revised by Thellung (1906), as L. neglectum (today included in L. densiflorum). However, it seems that the plants that arrived here accidentally from the West, via rail transport, were not able to naturalize in that initial point of introduction, which thus remained isolated on the distribution map. Although in the 1950s new introductions appeared independently of the initial introduction both in Crişana, and in eastern Transylvania, a significant wave of migration of this species cannot be recognized yet in these two provinces.

In the eastern Romania (Moldavia), L. densiflorum was collected in 1967, in Iaşi and Socola railway stations (Iaşi county), but confused with $L$. virginicum and distributed under that name in Flora Romaniae Exsiccata (FRE), no 3060, and Flora Moldaviae et Dobrogiae Exsiccata (FMDE), no. 40 (Negrean, 1980), a clear evidence that it was abundant in these localities at the time. After that year, an important increase in records of this species occurred in Moldavia, especially along railways. Populations of $L$. densiflorum from Moldavia could have originated from Ukraine, where this species is quite widespread and was first registered in 1895 (Protopopova et al., 2006). The fact that the first information about the occurrence of this species in
Moldavia come from two cities situated near the eastern border of Romania, along the railways linking Ukraine and Romania, can support this hypothesis.

In the southern regions of Romania $L$. densiflorum was first collected in Muntenia (1968), then in Oltenia (1976) (Negrean, 1980) and much later in Dobrudja (2011). We suppose that populations from southern regions are linked with those of Moldavia from where they could migrate along railways. The expansion from Transylvania, through mountain passes, toward eastern and southern regions of the country, cannot be excluded, but it is less likely, given that $L$. densiflorum is even nowadays a quite rare species in Transylvania. Probably it could not arrive in these regions either from the South, because it has not been registered yet in the southern neighbouring countries (Bulgaria, Serbia) (Akeroyd and Rich, 2010).

Lepidium virginicum is another North American species, widely naturalized in Europe (Akeroyd and Rich, 2010), as well as in Asia (Taiyan et al., 2001), South America, Africa, and Australia (Al-Shehbaz and Gaskin, 2010). According to Markgraf (1963), L. virginicum was introduced in the Botanic Garden of Montpellier, in 1697, and has been recorded in Central Europe as a subspontaneous plant, beginning with the eighteenth century (in 1786). Subsequently, it has gradually spread throughout the continent (Akeroyd and Rich, 2010; Markgraf, 1963; Thellung, 1906), mainly along railways. According to Lambdon et al. (2008), L. virginicum is currently one of the most widespread alien plant species in Europe, occurring in more than $80 \%$ of European regions.

In neighbouring countries of Romania, $L$. virginicum was reported in Hungary, in the beginning of the last century (Thellung, 1906), Serbia, in the 1970s (Ivković, 1978), the Caucasus region (Fedorov, 1979; Vinogradova $e t$ al. 2010), Ukraine (Protopopova et al., 1994), and in Turkey (Terzioğlu and Anşin, 2001).

In Romania, L. virginicum has arrived most probably from Central Europe, along railways, being recorded in 1910, in the North-West of the country (Crişana), near the actual border with Hungary (the Pişcolt village) (Karácsonyi, 1995). The previous indication from Crişana (at Ciucea village, leg. 1901) made by Degen (1902), is not a certain one, since subsequently in the monograph of the genus Lepidium, Thellung (1906) mentioned only " $L$. neglectum" from that locality: "1893, L. Richter - Herb. Degen".

After these first indications, the occurrence of this species was reported, almost simultaneously, at the middle of the last century, both in Crişana (Vadu Crişului railway station, Bihor County, leg. Soran, 03.VI.1951, herbarium CL-216713), and in three other provinces in the western half of the country, namely: Oltenia (herbarium CLA06400, Lotru railway station, leg. Nyárády, 19.VI.1950), Transylvania, in the Muşca railway canton, Alba county (leg. Soran, 1954) (Soran, 1962), and Banat, in the railway station of Câlnic, Caraş-Severin County (leg. Goga, 1955) (Goga, 1960). Reports on the presence of this species during such a short period of time (1950-1955) in localities so distant from one another $(100-250 \mathrm{~km})$, from four different provinces, suggests that in the first half of last century, an active spread of this species took place, along railways, 
starting from Crişana, the initial centre of introduction, southward, in Transylvania, Banat and Oltenia. However, we cannot exclude the hypothesis that new introductions occurred in all that time independently of the initial introduction. The introduction of this species in the southwestern Romania (Banat) from the neighbouring country (Serbia) is unlikely because there, L. virginicum was reported much later, in the 1970s (Ivković, 1978). In the subsequent decades, the spread of this species has continued along the railway network, especially in Banat, Crişana, and, to a lesser extent, in Oltenia (along the Olt River) and Transylvania. Also, L. virginicum migrated from Crişana to Maramureş, where it was first observed in 1974 (at railway station Ilba) (Negrean, 1980).

In Muntenia, L. virginicum was first collected in 1973, in the railway station Prahova, situated on the railway line Braşov-Bucharest. It was introduced there, probably, by rail transports, from Transylvania. The absence of this species in Bulgaria (Akeroyd and Rich, 2010) excludes its arrival in southern Romania from the Balkans.

In Moldavia, L. virginicum was recorded by error between 1967 and 1997, based on specimens of $L$. densiflorum, as mentioned above. Because of these wrong identifications, Negrean $(1980,1987)$ considered the presence of this species in Moldavia as uncertain. Indeed, upon examination of the herbarium specimens (I, IAGB, IASI) collected prior to 1997 , we found that all of them were wrongly determined, and that they belong actually to L. densiflorum (Sîrbu, 2006). L. virginicum has been found with certainty in Moldavia since 1997, being collected in the railway station of Socola-Iaşi (herbarium IASI - 17957, leg. Sîrbu and Oprea, 21.VII.1997) (Oprea et al., 1997). However, the current data indicate that it is quite widespread in Moldavia, mainly in railway stations. Since $L$. virginicum is missing in Republic of Moldova (Negru, 2007), and it was discovered only recently in Ukraine (Protopopova et al., 1994), we suppose this species arrived in eastern Romania either from the West (Transylvania), through mountain passes, or, more likely, from the South, along the railway lines linking Bucharest with the major cities of Moldavia.

In Dobrudja, L. virginicum was recently reported in a single locality (in Constanța harbour), by Anastasiu et al. (2009).

Lepidium oblongum originates in North America (Southern and Central USA) and Central America (Mexico, El Salvador, and Guatemala) (Al-Shehbaz and Gaskin, 2010; DiTomaso and Healy, 2007). There is a single record of this species in Romania (Sîrbu and Oprea, 2011), and according to Akeroyd and Rich (2010), and Drake (2009), it is so far unknown in other regions of Europe. In the railway station of Râmnicu Sărat, the population of $L$. oblongum consists of several dozens of individuals (Sîrbu and Oprea, 2011). Because their seeds have a high capacity of germination (over 80\%, in light conditions) (Sîrbu, 2011, unpublished), and the population persisted for three consecutive years in the same place, we can assume that this species is naturalized in Romania, even if it was reported only from a single location, so far. We suppose that it arrived in Râmnicu Sărat railway station with goods or passenger trains, but we do not know currently the ways of its migration from North America to Romania. As it was shown by many authors (e.g., Guo et al., 2012; Mihulka and Pyšek, 2001), there are often positive relationships between the latitudinal distributions occupied by species in their native and exotic ranges. As the primary area of L. oblongum extends up to Oregon (on the West coast of the United States) (DiTomaso and Healy, 2007), ca. $44^{\circ} \mathrm{N}$, we can suppose that it may have a potential to invade southern regions of Europe, but further studies are required in this regard.

\section{Lag time and invasion curves}

The spread of $L$. densiflorum and L. virginicum in Romania was initiated, as stated above, at the middle of the last century, about 60 , respectively 40 years after registration of the first specimen of these species in the country. This is not surprising since a lag time of over $40-50$ years between initial colonization and the onset of rapid population growth and geographic expansion is a common feature of alien plant invasions (Binggeli, 2001; Essl et al., 2009; Pyšek and Prach, 1993). The increase of the invasion slope after 1950 for both species could be related to the intensive railway transport of troops and military equipment, during the Second World War, as well as the environmental disturbances caused by that war.

According to our results, the slopes of invasion curves, which give global estimations of the invasion rates (Delisle et al., 2003) do not differ significantly for $L$. densiflorum and L. virginicum in Romania. However, periods of invasibility (i.e. sharp increase in slope of the invasion curve) differ between the two species in the second half of the last century. The active spread of $L$. virginicum has been recorded since 1950, with an important advance against $L$. densiflorum (1967). Moreover, evidence of naturalized populations occurred earlier in L. virginicum ( 45 years after first registration in Romania) as against $L$. densiflorum (84 years after first registration in Romania).

Since the invasion curve has an evident increasing trend in the last decade, for both L. densiflorum and L. virginicum, we can assume that the two species are still far from reaching the saturation phase of invasion in Romania - i.e. when the rate of invasion slows down (Essl et al., 2009), and that they will continue to spread in the future.

\section{Habitat preferences and the role of traffic lines in plant spreading}

Within their natural range, L. densiflorum, L. virginicum and $L$. oblongum grow in various disturbed natural and anthropogenic habitats, such as: prairies, pastures, waste grounds, fields, roadsides, railways (all three species) (AlShehbaz and Gaskin, 2010; DiTomaso and Healy, 2007), flood plains (L. densiflorum and L. oblongum), sagebrush flats, gravelly hillsides, rock crevices, seashores, sandy places, open mesa ( $L$. densiflorum), llanos, calcareous sand, alluvial terraces (L. oblongum) (Al-Shehbaz and Gaskin, 2010) etc. As for the species L. sativum, in its native area, it prefers not too warm sites, with rich, open soils, well supplied with water, although it is fairly drought tolerant (Bush 1939; Jansen 2004).

In Central Europe, according to Markgraf (1963), L. 
245

densiflorum and $L$. virginicum are usually found on nutrient-rich soils, in railway stations, between the tracks, along roads, on ruderal places, on sands and gravels in harbours, rarely as weeds in crops, entering in composition of the ruderal communities from the orders Sisymbrietalia and Onopordetalia. In Central Europe, L. sativum occasionally escapes from cultivation, in weed communities on newly disturbed fields, rich in nutrients (Sisymbrion) (Markgraf, 1963). In Romania, the Lepidium species taken into account invade a more limited range of habitats than in their natural areas, but (except L. oblongum) comparable with other regions in Europe.

It is well known that the repeated transport of propagules by trains or cars can facilitate the spread and naturalization of alien species along traffic lines (Hulme, 2009; Kowarik, 2003; Von der Lippe and Kowarik 2007). It is probably the case of species studied by us, except $L$. sativum. In more than $86 \%$, and respectively $74 \%$ of the total number of records in Romania, L. virginicum and respectively $L$. densiflorum grow in ruderal habitats associated with traffic infrastructure, and railway stations have the largest share in the total number of records. The predominance of these species in habitats associated to railways suggests that they immigrated to and spread throughout Romania mainly via the railway transport.

Consequently, it was expected that the spread of both species be influenced by extension of railway network, by intensity of goods and passenger traffic, as well as by disturbance status of habitats associated with railways. But the length of railway network in operation did not change significantly in Romania, in the last 60 years. Between 1950 and 1995, it increased only by 4.8\% (from 10853 to 11376 $\mathrm{km}$ ), and between 1995 and 2010 it even decreased by $5.2 \%$, reaching today below the level of the year 1950 (INSR, 1950-2011). In addition, surprisingly, for the period 19502010, we did not found significant positive relationships between the number of records of the species L. virginicum and $L$. densiflorum and the rail traffic of goods or passengers. Therefore, we can assume that the spread of both species was determined rather by the favourability of disturbed habitats associated with railways (especially ruderal habitats from train stations). This made possible the germination of seeds accidentally arrived with trains from long distances, and, subsequently, the growth of plants and seed production for several generations. Naturalized plants in new locations have further spread, via anemochorous, epizoochorous (over short distances) or anthropochorous seed dispersal (over variables distances), in ruderal habitats closely associated with railways and roads, as well as in other anthropogenic or natural habitats, on lands situated near transport routes. This agrees with the pattern of stratified dispersal, consisting of long-distance movements, and neighbourhood diffusion (Essl et al., 2009; Kowarik, 2003; Ming and Albrecht, 2004).

Overall, according to our data, it seems that $L$. densiflorum has a more pronounced tendency of diversifying the invaded habitats than $L$. virginicum. Only $L$. densiflorum has been reported so far in Romania as a segetal weed in cereal crops (Flora Olteniae Exsiccata, 951, leg. Păun, 21.VI.1976; Vițălariu et al., 1977), or in vineyards, on sandy soils (Negrean, 1980). According to Vițălariu et al.
(1977), in wheat crops, this species can achieve a significant level of weed infestation (300-400 individuals per $\mathrm{m}^{2}$ ). After 1980, however, further cases of crop infestation by this species have not been registered. In natural habitats, only $L$. densiflorum and L. virginicum (especially the first one) were found, on sandy lands and river beds, probably in conditions of ruderalization, but reports in this respect were only occasional.

\section{The reliability of the data set}

According to the data from literature (Chauvel et al., 2006; Crawford and Hoagland, 2009; Delisle et al., 2003; Pyšek and Prach, 1993; Pyšek and Hulme, 2005), to successfully reconstitute the introduction and invasion of a species on a large geographical scale through floristic data, a sufficient and constant intensity of floristic investigations within that area is necessary. This condition is broadly achieved in Romania, because of the strong and long tradition of floristic research in this country, dating back to the second decade of the 19th century. However, the reconstitution of plant invasions could be affected by the fluctuation in time of the interest shown by botanists to collect herbarium specimens, which may sharply decrease at one time, because a certain degree of saturation can be attained (Chauvel et al., 2006). Our data proved, for instance, that between 1950 and 1980, there was an increasing trend to collect herbarium specimens of $L$. densiflorum and L. virginicum, but no other specimen was collected over the next 15 years even though new records continued to appear in the published literature, all that time. Therefore, by using data from multiple sources (herbaria, published literature, field studies), we tried to reduce bias in assessing the patterns of invasion. On the other hand, we have no reasons to believe that botanists have tended to collect or record $L$. densiflorum more than $L$. virginicum, or vice versa. In fact they are very similar morphologically, as already shown, and usually grow in similar habitats. So, the recording effort could be considered similar for the two species over the time. However, such reconstitution remains unavoidably influenced by the magnitude of floristic investigations. Therefore, we suppose that $L$. densiflorum and $L$. virginicum are still underrecorded in Romania, and their genuine distribution could be larger than it is suggested by the currently available data used in this paper.

\section{Conclusions}

Four alien species of Lepidium were registered till now in the flora of Romania, of which one is casual (L. sativum), one naturalized ( $L$. oblongum), and two are invasive $(L$. densiflorum and $L$. virginicum). The invasion of the last two species started after a lag time of about 60 , respectively 40 years. Although both species were first reported in the northwestern Romania, they subsequently followed different paths of migration in the country. However, the slopes of the invasion curves do not differ significantly between the two species. The predominance of these invasive species in habitats associated to railways suggests that they immigrated to and spread throughout Romania mainly via the railway transport. Naturalized populations along railways have further dispersed to neighbouring 
suitable habitats, especially ruderal ones, following the pattern of the stratified dispersal. Although invasive, neither $L$. densiflorum nor $L$. virginicum proved to be harmful to crops or natural habitats, so far.

\section{Acknowledgements}

This work was partially supported by CNCSISUEFISCDI Romania, project number PN II-IDEI_1227. The authors thank the curators of the cited herbaria, the anonymous reviewers for their very helpful comments on the previous version of the manuscript, as well as Mr. Z. Barina and Mr. F. Verloove for providing some important references and herbarium specimens.

\section{References}

Akeroyd JR, Rich TCG (2010). Lepidium L., p. 398-402. In: Tutin TG, Burges NA, Chater AO, Edmondson JR, Heywood VH, Moore DM, Valentine DH, Walters SM, Webb DA (eds.). Flora Europaea, Vol. 1: Psilotaceae to Platanaceae, $2^{\text {nd }}$ ed., $1^{\text {st }}$. paperback printing, Cambridge University Press, Cambridge.

Al-Shehbaz IA (2010). A synopsis of the South American Lepidium (Brassicaceae). Darwiniana 48:141-167.

Al-Shehbaz IA, Gaskin JF (2010). Lepidium L., p. 570-595. In: Boufford D, Freeman C, Gandhi K, Hill M, Kiger R, Poole J, Schmidt H, Shultz L, Strother J, Zarucchi J (Eds.). Flora of North America, Vol. 7, Magnoliophyta: Salicaceae to Brassicaceae, Oxford University Press Inc., New York.

Anastasiu P, Negrean G, Făgăraş M, Samoilă C, Cogălniceanu D (2009). Constanța harbour (Romania) as a major gateway and reservoir for alien plant species. Acta Horti Bot Bucurest 36:41-60.

Baumgarten JCG (1816). Enumeratio stirpium Magno Transsilvaniae Principatui. Vol. 2, Libraria Camesinae, Vindobonae, $390 \mathrm{p}$.

Binggeli P (2001). Time-lags between introduction, establishment and rapid spread of introduced environmental weeds. Proc $3^{\text {rd }}$ Internat Weed Sci Congr; 2000 June 6-11; Foz do Iguassu, Brazil, Manuscript number 8-14 p, CD-ROM. Available from: International Weed Science Society, Oxford, MS, USA.

Bush NA (1939). Lepidium L., p. 501-524. In: Bush NA (Ed.). The Flora of USSR (in Russian), Vol. 8, Nauka, MoskvaLeningrad.

Chauvel B, Dessaint F, Cardinal-Legrand C, Bretagnolle F (2006). The historical spread of Ambrosia artemisiifolia L. in France from herbarium records. J Biogeogr 33:665-673.

Ciocârlan V (2009). Illustrated flora of Romania. Pteridophyta et Spermatophyta (in Romanian). 3rd ed. Edit. Ceres, Bucharest, $1141 \mathrm{p}$.

Crawford PHC, Hoagland BW (2009). Can herbarium records be used to map alien species expansion over the past 100 years? J Biogeogr 36:651-661.

Csontos P, Vitalos M, Barina Z, Kiss L (2010). Early distribution and spread of Ambrosia artemisizfolia in Central and Eastern Europe. Bot Helv 120:75-78.

Degen Á (1902). Lepidium virginicum L. Magyarors-Zágbau (Lepidium virginicum L. in Ungarn). Mag Bot Lap 1:349-350.

Delisle F, Lavoie C, Jean M, Lachance D (2003). Reconstructing the spread of invasive plants: taking into account biases associated with herbarium specimens. J Biogeogr 30:10331042.

DiTomaso JM, Healy EA (2007). Weeds of California and other western states. Vol. 1: Aizoaceae-Fabaceae. Agriculture and Natural Resources, University of California, $834 \mathrm{p}$.

Drake JA (Ed.) (2009). DAISIE handbook of alien species in Europe. Springer Science + Business Media BV, 399 p.

Essl F, Dullinger S, Kleinbauer I (2009). Changes in the spatiotemporal patterns and habitat preferences of Ambrosia artemisiifolia during its invasion of Austria. Preslia 81:119133.

Fedorov AA (1979). Flora of the European USSR (in Russian), Vol. 4. Nauka, Leningrad, 356 p.

Goga ID (1960). Euphorbia maculata L. and Lepidium virginicum L. and their spread in Banat (in Romanian). Comun Bot /1957-1959/:337-339.

Guo Q, Sax DF, Qian H, Early R (2012). Latitudinal shifts of introduced species: possible causes and implications. Biol Invasions 14:547-556.

Heuffel J (1858). Enumeratio plantarum in Banatu Temesiensi sponte crescentium et frequentius cultarum. Typis Caroli Ueberreuter, Vindobonae, $204 \mathrm{p}$.

Holmgren PK, Holmgren NH, Barnett LC (1990). Index herbariorum, Part I: the herbaria of the world [Regnum Veg. vol. 120], New York Botanical Garden Press, New York.

Hulme PE (2009). Trade, transport and trouble: managing invasive species pathways in an era of globalization. J Appl Ecol 46:10-18.

INSR (Institutul National de Statistica al României) (1950-2011). Statistical yearbook of Romania (in Romanian). Edit. INSR, Bucharest.

Ivković O (1978). Lepidium virginicum L. 1753 (Capparidales, Brassicaceae), a new species in the flora of Serbia (in Serbian). Biosistematika Beograd 4(1):75-79.

Jansen PCM (2004). Lepidium sativum L., In: Grubben GJH, Denton OA (Eds.). PROTA 2: Vegetables/Légumes. [CDRom]. PROTA, Wageningen, Netherlands.

Karácsonyi C (1995). Flora and vegetation of Satu Mare county (in Romanian). Edit. Muz. Sătmărean, Satu Mare, 196 p.

Kowarik I (2003). Human agency in biological invasions: secondary releases foster naturalisation and population expansion of alien plant species. Biol Invasions 5:281-300.

Lambdon PW, Pyšek P, Basnou C, Hejda M, Arianoutsou M, Essl F, Jaroší V, Pergl J, Winter M, Anastasiu P, Andriopoulos P, Bazos I, Brundu G, Celesti-Grapow L, Chassot P, Delipetrou P, Josefsson M, Kark S, Klotz S, Kokkoris Y, Kühn I, 
247

Marchante H, Perglová I, Pino J, Vilà M, Ziko A, Roy D, Hulme PE (2008). Alien flora of Europe: species diversity, temporal trends, geographical patterns and research needs. Preslia 80:101-149.

Lavoie C, Jodoin Y, Goursaud de Merlis G (2007). How did common ragweed (Ambrosia artemisiifolia L.) spread in Quebec? A historical analysis using herbarium specimens. J Biogeogr 34(10):1751-1761.

Lehrer AZ, Lehrer MM (1990). Mapping of fauna and flora of Romania (areographic coordinates) (in Romanian). Edit. Ceres, Bucharest, 295 p.

Markgraf F (1963). Lepidium L., p. 401-417. In: Hegi G., Illustrierte Flora von Mitteleuropa. Band 4(1/6), 2 Aufl., Carl Hanser Verlag, München.

McDonald JH (2008). Handbook of biological statistics. Baltimore: Sparky House Publishing, 287 p.

Mihulka S, Pyšek P (2001). Invasion history of Oenothera congeners in Europe: a comparative study of spreading rates in the last 200 years. J Biogeogr 28:597-609.

Ming P, Albrecht J (2004). Integrated framework for the simulation of biological invasions in a heterogeneous landscape. Transactions in GIS 8(3):309-334.

Negrean G (1980). Lepidium densiflorum and Lepidium neglectum in Romania (in Romanian). Stud Comun Muz Satu Mare 4:435-439.

Negrean G (1987). Additions to the flora of Romania (in Romanian). Stud Comun Muz Satu Mare 7-8:447-459.

Negru A (2007). Identification book of plants from the flora of the Republic of Moldova (in Romanian). Edit. Universul, Chişinău, 391 p.

Nyárády EI (1955). Lepidium L., p. 418-431. In: Săvulescu T (Ed.), Flora of the Romanian People's Republic (in Romanian), Vol. 3, Edit. Academiei R. P. Române, Bucharest.

Oprea A, Sîrbu C, Paraschiv NL (1997). Flora and vegetation from the Socola-Iaşi railway station, I. Flora (in Romanian). Lucr Şti USAMV Iaşi, Agricult 40:91-97.

Panțu ZC (1912). Contributions to the flora of Bucharest and surroundings (in Romanian), IV. Analele Acad Române, Mem Secț Şti, Ser II 34:435-598.

Pénzes A (1941). On the recent spread of some species of Eragrostis and Lepidium (in Hungarian). Bot Közlem 38(34):179-180.

Prodan I (1939). Flora for identification and description of plants that grow in Romania (in Romanian), Vol. 1, part. 1, 2nd ed. Tipogr. Cartea Românească, Cluj, 624 p.

Protopopova VV, Mosyakin SL, Shevera MV (1994). Lepidium virginicum L. - a new alien species in Ukrainian flora (in Ukrainian). Ukrayins'k Bot Zhurn 51(2-3):225-228.
Protopopova VV, Shevera MV, Mosyakin SL (2006). Deliberate and unintentional introduction of invasive weeds: a case study of the alien flora of Ukraine. Euphytica 148:17-33.

Pyšek P, Hulme P (2005). Spatio-temporal dynamics of plantinvasions: linking pattern to process. Ecoscience 12:302-315.

Pyšek P, Prach K (1993). Plant invasions and the role of riparian habitats: a comparison of four species alien to central Europe. J Biogeogr 20:413-420.

Richardson DM, Pyšek P, Rejmánek M, Barbour MG, Panetta FD, West CJ (2000). Naturalization and invasion of alien plants: concepts and definitions. Diversity Distrib 6:93-107.

Schur JF (1866). Enumeratio plantarum Transsilvaniae. Apud Guilielmum Braumüller, Vindobonae, 984 p.

Simonkai L (1886). Erdély edényes flórájának helyesbített foglalata (Enumeratio florae Transsilvaniae vesculosae critica). Kiadja A Kir. Magyar Természettudományi Társulat, Budapest, 678 p.

Sîrbu C (2006). Floristic and chorological contributions from Moldavia and Muntenia (Romania). Analele Şti Univ “Alexandru Ioan Cuza” Iaşi, Biol veg 52:92-98.

Sîrbu C, Oprea A (2011). Alien plants of the flora of Romania (in Romanian). Edit. "I. I. de la Brad", Iaşi, 733 p.

Soran V (1962). Research on weeds and their association in the Apuseni Mountains (in Romanian). Probl Biol 299-346.

Taiyan Z, Lianli L, Guang Y, Al-Shehbaz IA (2001). Brassicaceae (Cruciferae), p. 1-193. In: Flora of China, Editorial Committee (Eds.). Flora of China, Vol. 8. Science Press, Beijing and St. Louis, Botanical Garden Press, Missouri.

Terzioğlu S, Anşin R (2001). A chorological study on the taxa naturalized in the Eastern Black Sea Region. Turk J Agric For 25:305-309.

Thellung A (1906). Die Gattung Lepidium (L.) R. Br. Eine monographische Studie. Neue Denkschr Schweiz Naturf Ges 41:1-340.

Vinogradova JK, Majorov SR, Chorun LV (2010). The black data book of the flora of Middle Russia (in Russian). GEOS, Moskva, 512 p.

Vițălariu G, Zanoschi V, Turenschi E (1977). Phyto-chorological contributions for Moldavia and Dobrudja (in Romanian). Analele Şti Univ “Alexandru Ioan Cuza” Iaşi, Biol 23:25-27.

Von der Lippe M, Kowarik I (2007). Long-distance dispersal of plants by vehicles as a driver of plant invasions. Conservation Biol 21(4):986-996.

Williamson M, Pyšek P, Jarošyk V, Prach K (2005). On the rates and patterns of spread of alien plants in the Czech Republic, Britain, and Ireland. Ecoscience 12(3):345-354.

Zar JH (2010). Biostatistical analysis. 5th ed. Prentice Hall Inc, New Jersey, 944 pp. 